\title{
Fetal Rhesus Monkey First Trimester Zika Virus Infection Impacts Cortical Development in the Second and Third Trimesters
}

\author{
Alice F. Tarantal ${ }^{1,2,3}$, Dennis J. Hartigan-O'Connor ${ }^{3,4}$, Elisa Penna(15 ${ }^{5}$, \\ Anna Kreutz ${ }^{5}$, Michele L. Martinez ${ }^{3}$ and Stephen C. Noctor ${ }^{5,6}$ \\ ${ }^{1}$ Department of Pediatrics, School of Medicine, University of California, Davis, Davis, CA 95616, USA, \\ ${ }^{2}$ Department of Cell Biology and Human Anatomy, School of Medicine, University of California, Davis, Davis, \\ CA 95616, USA, ${ }^{3}$ California National Primate Research Center, University of California, Davis, Davis, CA 95616, \\ USA, ${ }^{4}$ Department of Medical Microbiology and Immunology, School of Medicine, University of California, \\ Davis, Davis, CA 95616, USA, ${ }^{5}$ Department of Psychiatry and Behavioral Science, School of Medicine, University \\ of California, Davis, Davis, CA 95817, USA and ${ }^{6}$ MIND Institute, School of Medicine, University of California, \\ Davis, Davis, CA 95817, USA
}

Address correspondence to Dr. Alice F. Tarantal, Departments of Pediatrics and Cell Biology and Human Anatomy, School of Medicine, California National Primate Research Center, University of California, Davis, One Shields Avenue, Davis, CA 95616-8542, USA. Email: aftarantal@ucdavis.edu; and Dr. Stephen C. Noctor, Department of Psychiatry and Behavioral Science, MIND Institute, University of California, Davis, One Shields Avenue, Davis, CA 95616-8542, USA. Email: scnoctor@ucdavis.edu.

\begin{abstract}
Zika virus is a teratogen similar to other neurotropic viruses, notably cytomegalovirus and rubella. The goal of these studies was to address the direct impact of Zika virus on fetal development by inoculating early gestation fetal rhesus monkeys using an ultrasound-guided approach (intraperitoneal vs. intraventricular). Growth and development were monitored across gestation, maternal samples collected, and fetal tissues obtained in the second trimester or near term. Although normal growth and anatomical development were observed, significant morphologic changes were noted in the cerebral cortex at 3-weeks post-Zika virus inoculation including massive alterations in the distribution, density, number, and morphology of microglial cells in proliferative regions of the fetal cerebral cortex; an altered distribution of Tbr2 ${ }^{+}$neural precursor cells; increased diameter and volume of blood vessels in the cortical proliferative zones; and a thinner cortical plate. At 3-months postinoculation, alterations in morphology, distribution, and density of microglial cells were also observed with an increase in blood vessel volume; and a thinner cortical plate. Only transient maternal viremia was observed but sustained maternal immune activation was detected. Overall, these studies suggest persistent changes in cortical structure result from early gestation Zika virus exposure with durable effects on microglial cells.
\end{abstract}

Key words: fetus, microglia, monkey, vasculature, Zika virus 


\section{Introduction}

Zika virus remains a global public health concern (CDC 2020; Mulkey et al. 2020; Pierson and Diamond 2020; Sharma et al. 2020). Zika virus has distributed across Africa, the Americas, Asia, and the Pacific, with virus detected in blood, semen, saliva, and urine. Known modes of transmission include mosquito, vertical, and sexual transmission (Aliota et al. 2017; Hastings and Fikrig 2017; Counotte et al. 2018; Arora 2020), and potentially through the blood supply (Jimenez et al. 2017; Eick et al. 2019). It has been reported that Zika virus can infect human cortical neural progenitor cells in vitro (Hanners et al. 2016; Souza et al. 2016; Tang et al. 2016; Ferraris et al. 2019; Gratton et al. 2020), human neurospheres and brain organoids (Garcez 2016; Sutarjono 2019), and microglia (Lum et al. 2017). Zika virus has been identified as a teratogen similar to other neurotropic viruses, notably cytomegalovirus (CMV) and rubella (Neu et al. 2015; Coyne and Lazear 2016; Rasmussen et al. 2016). Animal models have been employed to gain insight into the impact of Zika virus on the developing fetus (Newman et al. 2017; Caine et al. 2018; Dudley et al. 2019; Xu et al. 2019).

As demonstrated in our CMV studies, the rhesus monkey model provides strategic advantages when compared with other species particularly for addressing potential viral teratogens (Barry et al. 2006). Examples of similar developmental features when comparing humans and rhesus monkeys include gestational length; growth characteristics; hematopoietic, immune system, and organ ontogeny; and placental structure to name a few (Ramsey et al. 1976; Lee et al. 2005; Tarantal 2005; Batchelder et al. 2014; Barger et al. 2019). Neurodevelopmentally, the production of cortical neurons in rhesus monkeys follows the "inside out" sequence (Rakic 1974), and the proliferative zones of the fetal monkey cerebral cortex possess the same classes of neural precursor cells that exhibit the same distribution, morphology, protein, and transcription factor expression present in other animal models (Martínez-Cerdeño et al. 2012). Thus, key features of cortical development are shared by rhesus monkeys and humans (Cunningham et al. 2013a,b). Further, in both species the neural precursor cell pool is greatly expanded, and microglial colonization is more extensive than, for example, in rats. In both humans and nonhuman primates, the proliferative zones of the prenatal cortex are populated by neurogenic precursor cells including $\mathrm{Pax}^{+}$radial glial cells, Tbr2 ${ }^{+}$intermediate progenitor cells, $\mathrm{Pax}^{+}$translocating radial glial cells, $\mathrm{Pax}^{+}$astroglial precursor cells, and oligodendroglial precursor cells (MartínezCerdeño et al. 2012; Cunningham et al. 2013a,b). Our prior studies have also shown that there is more extensive microglial colonization and phagocytosis of neural precursors in fetal human and rhesus monkey brains when compared with other species such as rats (Barger et al. 2019; Noctor et al. 2019).

In the normally developing fetal rhesus monkey, proliferative cortical neural precursor cells reside in the ventricular zone (VZ) adjacent to the lateral ventricle, and in the subventricular zone (SVZ) that is superficial to the VZ (Smart et al. 2002; MartínezCerdeño et al. 2012; Cunningham et al. 2013a). In the second trimester mitotic neural precursor cells produce cortical neurons destined for cortical layers 4 and 5 (Rakic 1974), microglial cells begin to colonize cortical proliferative zones (Cunningham et al. 2013b), fetal microglia interact closely with mitotic neural precursor cells, and they regulate the size of the precursor cell pool through cellular phagocytosis (Cunningham et al. 2013b; Barger et al. 2019; Noctor et al. 2019). Microglia-a specialized population of macrophage-like cells in the central nervous system (CNS) (Kettenmann et al. 2011; Bachiller 2018)—display the morphological phenotype of "activated" cells in the normally developing fetal rhesus cortex. These cells extend a few thick processes, and some display large amoeboid somata with no processes or a few thin processes (Cunningham et al. 2013b; Barger et al. 2019). Microglia arise outside of the CNS (Ginhoux et al. 2010) and begin entering the developing human brain during the first trimester. However, rather than distributing evenly throughout the brain, microglial cells initially concentrate in specific laminae, including the proliferative germinal zones that surround the ventricular system, and in the pial meninges (Rezaie and Male 1999; Cunningham et al. 2013b). Evidence suggests a link between microglial function and neurodevelopmental disorders (Sekar et al. 2016; Wolf et al. 2017; Bachiller 2018)

Understanding how microglial cells populate the developing primate brain remains incomplete, and the impact of Zika virus during critical developmental stages is not well understood. Thus, these studies focused on the impact of Zika virus on the developing fetus and utilized a direct ultrasound-guided inoculation approach to specifically address how the virus can alter developmental timelines when administered systemically (fetal intraperitoneal, IP) or intracranial (IC, within the lateral ventricles) in the late first trimester. These studies also explored the impact of Zika virus on immune system activation and in relation to neurodevelopmental findings.

\section{Materials and Methods}

\section{Rhesus Monkeys}

All animal procedures conformed to the requirements of the Animal Welfare Act, and protocols were approved prior to implementation by the Institutional Animal Care and Use Committee at the University of California, Davis. Female rhesus monkeys $(N=13)$ were time-mated and identified as pregnant by ultrasound according to established methods (Tarantal 2005). Prior to study assignment normal embryonic growth and development were confirmed by ultrasound. Activities related to animal care were performed according to California National Primate Research Center standard operating procedures.

\section{Zika Virus}

Zika virus PRVABC59 aliquots (Zika virus/H.sapiens-tc/PUR/2015/ PRVABC59) were kindly provided by Dr David O'Connor (GenBank: KU501215), University of Wisconsin, Madison. A wellcharacterized batch (NR-50240, human blood Puerto Rico, 2015) was used for all studies. Aliquots were thawed immediately prior to fetal inoculation ( $\sim 0.1-0.3 \mathrm{~mL}, 10^{4}$ plaque forming units [PFU]/fetus).

\section{Fetal Inoculation, Ultrasound Monitoring, and Sample Collection}

Early gestation ( $\sim 50$ days; late first trimester) fetal rhesus monkeys were directly inoculated using an ultrasound-guided IC $(\mathrm{N}=3)$ or IP approach $(\mathrm{N}=6)$ as previously described (Chang et al. 2002; Tarantal 2005; Jimenez et al. 2005; Barger et al. 2019). Three fetuses were inoculated IC (IC \#1-3; 0.1 mL) and 6 were inoculated using a fetal IP approach (IP \#1-6; 0.3 mL). Trimesters in rhesus monkeys are divided by 55 -days increments with the first trimester representing 0-55 days gestation, the second trimester 
A.
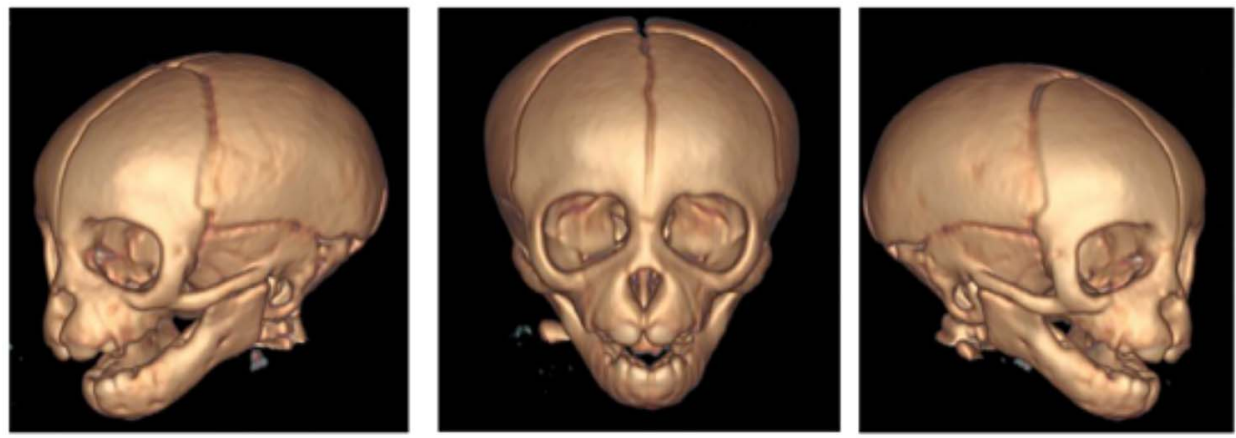

B.

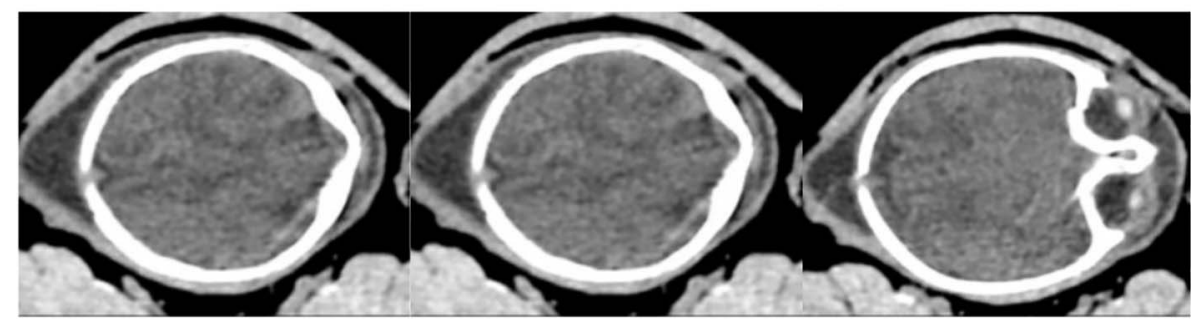

Figure 1. Sedated dams were placed within plexiglass containment with open ports covered by mosquito netting for biocontainment. (A) In utero fetal CT scans were conducted immediately following ultrasound examinations (once or twice; second and third trimesters) during gestation. Cropped images focusing on the fetal cranium are shown (early third trimester; 3D reconstruction) with no evidence of anatomical changes including within soft tissue structures (transverse sections shown) (B).

56-110 days gestation, and the third trimester 111-165 days (term $165 \pm 10$ days) (Tarantal 2005). Four fetuses of comparable gestational age served as controls. Ultrasound examinations were performed prior to inoculation to confirm normal growth and development then every $\sim 7-10$ days postinoculation under ketamine or telazol sedation. Standardized parameters were assessed including fetal growth (biparietal and occipitofrontal diameters, abdominal circumference, humerus, and femur lengths) and structural development, amniotic fluid volumes and placental parameters, which were compared to normal growth and developmental trajectories for the species (Tarantal 2005). Dams were weighed at each sedation for imaging (all within normal limits), and blood (complete blood counts, chemistry panels, and viral loads-qPCR) and urine samples ( $\sim 1 \mathrm{~mL}$ under ultrasound guidance; qPCR) were collected according to established protocols. Computed tomography (CT) scans were performed immediately after ultrasound examinations once or twice during the study period depending on the study group (Fig. 1). Dams were scheduled for hysterotomies per study group and the gestational sac removed for complete fetal tissue assessments (Jimenez et al. 2005; Tarantal et al. 2005).

Amniotic fluid, fetal blood, and fetal cerebrospinal fluid (CSF) were collected, then fetal body weights and measures (biparietal, occipitofrontal diameters; head, arm, chest circumferences; hand, foot, humerus, femur lengths; crown-rump length; data not shown, all within normal limits) were assessed and select organs weighed (brain, spleen, thymus, adrenal glands, kidneys, liver, thyroids; data not shown, all within normal limits). Specimens collected for qPCR included dura mater; right and left cerebral hemispheres (frontal, parietal, temporal, occipital lobes; in addition to coronal sections from the frontal lobe, parietal/temporal lobes, and occipital lobe for immunohistochemical analysis, see below); cerebellum (right and left) and midbrain; right and left optic nerves; right and left eyes (cornea, retina, and sclera); spinal cord (cervical, thoracic, and lumbar); dorsal root ganglia; right and left parotids, submandibular, and salivary glands; omentum; thymus; spleen; liver (right, left, quadrate, and caudate lobes); pancreas; right and left adrenal glands and kidneys; right and left axillary and inguinal lymph nodes; diaphragm; tracheobronchial and mesenteric lymph nodes; right and left thyroids; trachea; esophagus; pericardium; aorta; right and left atria and ventricles; lung lobes (right and left; all lobes); reproductive tract including right and left gonads; urinary bladder; gastrointestinal tract (stomach, duodenum, jejunum, ileum, colon; meconium); skin; skeletal muscle; and bone marrow. The placenta was weighed and assessed including primary and secondary disk measures, umbilical cord and membrane insertion sites, blood vessel distribution, cut surfaces, and presence of infarcts (all within normal limits). Decidua, membranes, umbilical cord, and multiple sections of the placental disks including the maternal and fetal sides of the placenta were collected. All specimens were quick frozen in triplicate over liquid nitrogen for qPCR, and multiple blocks of tissues were collected for histopathology (hematoxylin and eosin, H\&E) and immunohistochemistry (Tarantal et al. 2005; Batchelder et al. 2014; Barger et al. 2019; Noctor et al. 2019). Similar specimens were collected from the dams at tissue harvest (day of hysterotomy or up to 11-months posthysterotomy) in addition to reproductive tract draining lymph nodes.

\section{Quantitative PCR}

Viral RNA was isolated from $140 \mu \mathrm{L}$ of EDTA-anticoagulated cell-free plasma or urine using the QIAamp Viral RNA Mini kit 
(Qiagen, Valencia, CA) as recommended by the manufacturer. Tissues were processed for viral RNA using the Allprep DNA/RNA Mini kit (Qiagen) using the QIAcube (Qiagen) as recommended by the manufacturer. cDNA was then synthesized using random primers and the Sensiscript Reverse Transcriptase kit (Qiagen) according to the manufacturer's protocol. Quantification of viral load was performed by real-time PCR using the Taqman amplification system. The primers and probe were as follows: forward 5'- CGYTGCCCAACACAAGG3', reverse 5'-CCACYAAYGTTCTTTTGCABACAT-3', and probe 5'-FAM-AGCCTACCTTGAYAAGCARTCAGACACYCAA-TAMSp-3'. Real-Time quantitative PCR analysis was carried out in 96-well optical plates using the QuantStudio $12 \mathrm{~K}$ Flex Real-Time PCR System (ThermoFisher Scientific, Grand Island, NY) and the TaqMan Universal PCR Master Mix (ThermoFisher Scientific) according to the manufacturer's protocols. PCR reactions were run in triplicate in separate wells and contained $1 \times$ TaqMan universal master mix with $600 \mathrm{nM}$ of forward and reverse primers and $100 \mathrm{~nm}$ probe in a $25-\mu \mathrm{L}$ reaction volume. Cycling conditions were as follows: 1 cycle of $2 \mathrm{~min}$ at $50{ }^{\circ} \mathrm{C}, 15 \mathrm{~min}$ at $95^{\circ} \mathrm{C}$, followed by 50 cycles at $15 \mathrm{~s}$ at $95^{\circ} \mathrm{C}$, and $60 \mathrm{~s}$ at $60^{\circ} \mathrm{C}$.

\section{Flow Cytometry}

The activation state of circulating maternal and fetal immune cells was assessed by flow cytometry. Two aliquots were stained with panels organized around activation phenotypes relevant to antigen presenting cells or T-cells. Antibodies used at optimal concentrations included those reactive to CD3, CD4, CD8, CD11b, CD11c, CD14, CD16, CD20, CD25, CD28, CD80, CD95, CD127, CCR5, CXCR5, HLA-DR, NKG2A, and PD-1. Data were collected on a BD Fortessa or FACSymphony cytometer and analyzed in FlowJo.

\section{Immunohistochemical Analysis}

Coronal sections of the fetal brain $\sim 3-\mathrm{mm}$ thick were obtained from the frontal lobe, parietal/temporal lobes, and occipital lobe and immersion-fixed in 4\% paraformaldehyde (PFA) for 3-4 days. After fixation tissue was rinsed in $0.1 \mathrm{M}$ phosphate buffered solution $\mathrm{pH} 7.4$ (PBS) containing $0.01 \% \mathrm{NaN}_{3}$ (weight per volume) $3 \times 12 \mathrm{~h}$. Blocks of tissue were embedded in 3.5\% low melting point agarose and cut in the coronal plane at $100 \mu \mathrm{m}$ on a vibratome, and collected in either PBS with $0.01 \% \mathrm{NaN}_{3}$ for immunostaining, or tissue collecting solution (25\% glycerol, $30 \%$ ethylene glycol in $0.1 \mathrm{M} \mathrm{PBS}$ ) for storage at less than or equal to $-20{ }^{\circ} \mathrm{C}$ until analysis.

Prior to immunostaining, sections were rinsed sequentially in PBS 3 times for $1 \mathrm{~h}$ at $4{ }^{\circ} \mathrm{C}$, overnight in PBS at $4{ }^{\circ} \mathrm{C}$, and the following day $3 \times 1 \mathrm{~h}$ in PBS on a shaker at room temperature. Antigen retrieval was carried out for some staining by heating sections at $37^{\circ} \mathrm{C}$ for $30 \mathrm{~min}$ in $10 \mathrm{mM}$ citrate buffer, $\mathrm{pH}$ 3.5. After the citrate buffer returned to room temperature sections were rinsed $3 \times 5 \mathrm{~min}$ and incubated in a blocking buffer containing 10\% donkey serum (Millipore), $0.2 \%$ gelatin (ThermoFisher Scientific), and $0.1 \%$ Triton X-100 (ThermoFisher Scientific) for $1.5 \mathrm{~h}$ at room temperature. Sections were incubated overnight on a shaker at $4{ }^{\circ} \mathrm{C}$ in antibody incubation buffer (PBS with $2 \%$ donkey serum, $0.2 \%$ gelatin, and $0.1 \%$ Triton $\mathrm{X}-100$ ) and a cocktail containing 3 of the following primary antibodies and/or stains: chicken anti-Iba1 (1:150, SySy, 234006) to label microglial cells, goat anti-GFAP (1:50, Santa Cruz, SC-6171) to label astrocytes, mouse anti-NeuN (1:200, Millipore, MAB377) to label neurons, rabbit anti-Tbr2 (1:100, Abcam, ab23345) to label neural precursor cells, rabbit anti-phosphohistone H3 (PH3, 1:50, Millipore) to label M-phase dividing cells, or Isolectin GS-IB4 AlexaFluor 568 (1:500, Invitrogen). The next day sections were rinsed $3 \times 15$ min in PBS and incubated for $2 \mathrm{~h}$ at room temperature in antibody incubation buffer containing donkey anti-mouse, donkey antichicken, and donkey anti-goat secondary antibodies (1:250, Jackson Immunoresearch) conjugated to the fluorophores AF405, AF488, TRITC, or AF647. Sections were stained with DAPI (Sigma, 1:1000 in PBS) for $15 \mathrm{~min}$, rinsed $3 \times 5 \mathrm{~min}$ in PBS, mounted on SuperFrost slides (Fisher), and coverslipped with Mowiol. Apoptotic cells were labeled with a TUNEL kit (ThermoFisher Scientific).

Images of fluorescently immunostained sections were obtained on an Olympus Fluoview 1000 confocal microscope. At least 2 images of the cortical proliferative zones were obtained from 3 sections from each lobe of each fetus for analysis. Threedimensional reconstructions of immunopositive cells (Iba1 ${ }^{+}$ cells, IB4 ${ }^{+}$vessels) that were fully captured in confocal Zstacks were used to quantify and compare cell number, volume, distribution, and morphology between groups using Imaris image analysis software (Bitplane, Concord, MA). Double blind analysis was performed when using Imaris software to analyze parameters of cell morphology (5 cells per section) that included average process length, mean process diameter, the total sum of process length $(\mu \mathrm{m})$ per microglia, the number of process branches and process terminal points, average process area, process branching angle, process straightness, sum of process area, and the number of Sholl intersections. Data for imaged cells and structures were reported as the average \pm standard deviation and derived from samples from each fetus. T-tests were performed for comparison between 2 groups, and 1-way analysis of variance (ANOVA) for multiple group comparisons were performed with a 2-tailed $P$-value nonparametric test using Graphpad Prism (Graphpad Software, Inc.).

\section{Results}

\section{Fetal Outcomes Postvirus Inoculation}

Female rhesus monkeys were time-mated and identified as pregnant by ultrasound using well-established methods (Tarantal 2005). Three fetuses were directly inoculated IC under ultrasound guidance and six were inoculated using a fetal IP approach in the late first trimester ( $\sim 50$-days gestation). Four fetuses of comparable gestational age served as controls. Normal growth and development were observed for all fetuses throughout the study period (ultrasound, CT scans). Fetal tissues were collected by hysterotomy in the second (70-days gestation) or late third trimester ( 145 -days gestation; term $165 \pm 10$ days) as scheduled.

\section{Molecular Analysis: qPCR}

Maternal viral loads were followed longitudinally (day of inoculation then weekly for $\sim 1$ month then every 2-3 weeks postinoculation) until hysterotomy. Transplacental transfer of Zika virus from the fetus into the maternal circulation was shown to occur soon after fetal inoculation $(P=0.003$ for inverse association of gestational age with log-odds of detection) (Fig. 2A). The viral loads ranged from $1.8 \times 10^{3}$ to $4.9 \times 10^{4}$ Zika virus copies/ml. In one case Zika virus was detected a second time in maternal blood at 7-weeks 

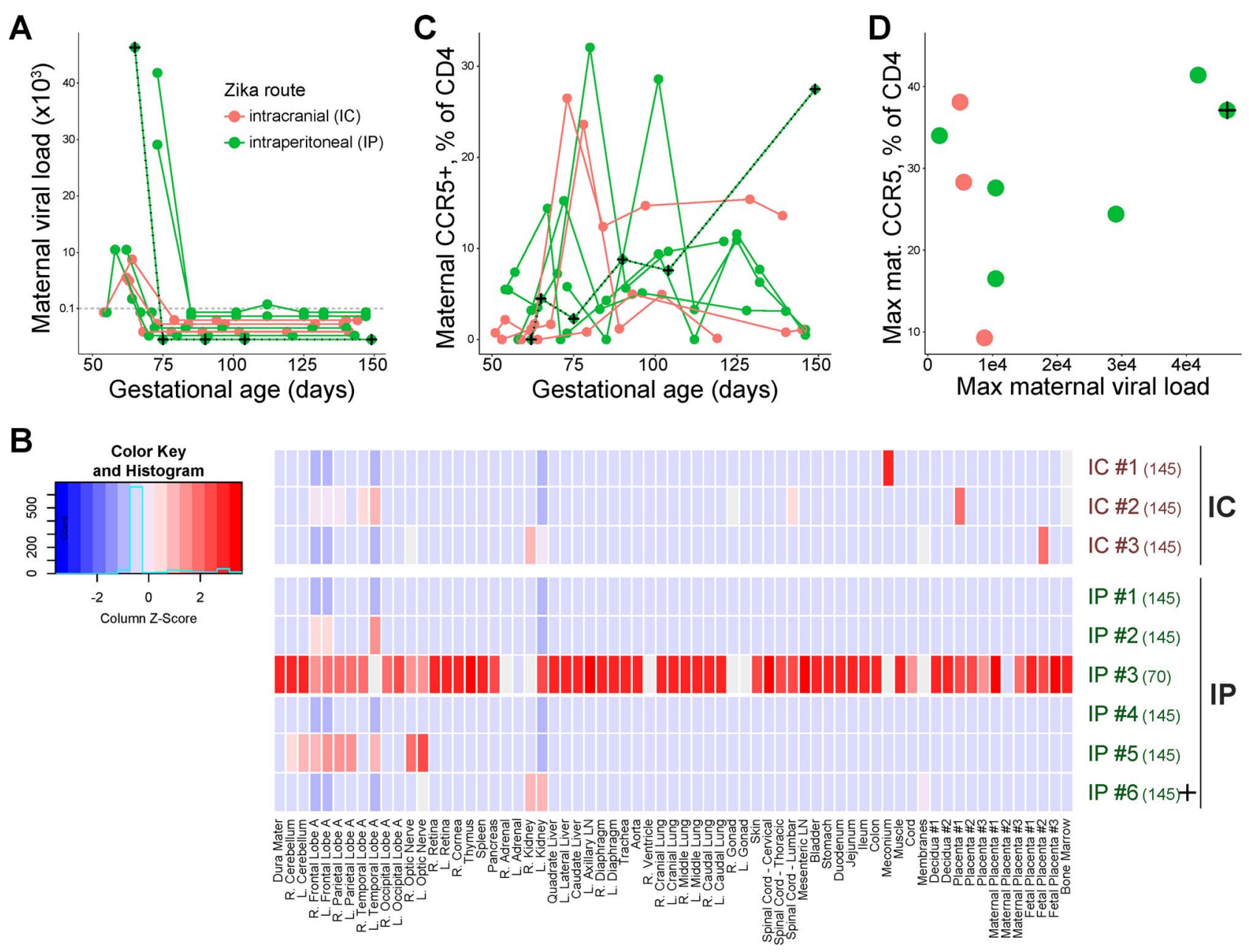

Figure 2. Viral loads and flow cytometry. (A) Maternal viral loads were followed longitudinally until hysterotomy. Transfer of virus from the fetus to the dam occurred soon after fetal inoculation. (B) Fetal tissues were extensively assessed following hysterotomy at 70-days (3-weeks postinoculation) or $\sim 145$-days gestational age (3-months postinoculation; term $165 \pm 10$ days). Selected tissues shown. IC = intracranial, IP =intraperitoneal, $R=$ right, $\mathrm{L}=$ left, $\mathrm{LN}=$ lymph node. (C) Maternal immune activation, reflected in CCR5 expression by CD4 ${ }^{+}$T-cells, followed a pattern of early up regulation followed by later decline. (D) Maximum maternal viral loads and CCR5 expression appeared to be associated; increased expression of CCR5 followed the early spike in maternal viral loads by 10-30 days. Animal IP \#6 had the highest maternal viral load and near-highest maternal CCR5 expression ("+" marker in all figures and a dotted line overlaid on traces; see Fig. 6H).

postfetal inoculation (IP). Maternal urine was negative at all time points assessed (blood and urine collected at the same time points across gestation; urine analyzed on the days of collection).

Fetal tissues were extensively assessed following hysterotomy at 70 days (3-weeks postinoculation) or $\sim 145$ days (3months postinoculation) gestational age (Fig. 2B). All weights and measures were within normal limits for the age groups. The Zika-inoculated fetus with tissues collected at 70-days gestation ( 3 weeks post-IP inoculation) developed massive, disseminated infection. Zika virus-positive fetal tissues included the cerebral hemispheres (right and left frontal, parietal, temporal, occipital lobes; range $1.0 \times 10^{3}-6.1 \times 10^{4}$ copies $\left./ \mathrm{mg}\right)$, cerebellum $\left(2.3 \times 10^{4}-\right.$ $5.2 \times 10^{4}$ copies $\left./ \mathrm{mg}\right)$, dura $\left(2.4 \times 10^{2}\right.$ copies $\left./ \mathrm{mg}\right)$, optic nerve $\left(2.3 \times 10^{1}-2.9 \times 10^{2}\right.$ copies $\left./ \mathrm{mg}\right)$, retina and cornea $\left(1.9 \times 10^{2}-\right.$ $2.9 \times 10^{3}$ copies $/ \mathrm{mg}$ ), spinal cord (cervical, thoracic, lumbar; $5.8 \times 10^{3}-1.4 \times 10^{4}$ copies $\left./ \mathrm{mg}\right)$, thymus $\left(7.8 \times 10^{5}\right.$ copies $\left./ \mathrm{mg}\right)$, kidneys $\left(2.0 \times 10^{5}\right.$ copies $\left./ \mathrm{mg}\right)$, as well as others. Decidua $\left(1.1 \times 10^{3} \mathrm{copies} / \mathrm{mg}\right)$, membranes (amnion and chorion; $2.1 \times 10^{4}$ copies/mg), and placenta $\left(9.9 \times 10^{3}\right.$ copies $\left./ \mathrm{mg}\right)$ were also
Zika virus positive. The tissues of the dam were assessed $\sim 11$-months posthysterotomy and all tissues were negative at that time.

A subset of fetal specimens was Zika virus positive at 3-months postinoculation and in most cases at low copy numbers. With IC administration, Fetus \#1 was negative in all tissues and the only positive sample was meconium $\left(1.9 \times 10^{3}\right.$ copies/mg; dam all tissues negative at 6 -months posthysterotomy). Fetus \#2 showed low copy numbers in select tissues (frontal, parietal, temporal lobes; spinal cord; 1.5$\left.8.2 \times 10^{1} \mathrm{copies} / \mathrm{mg}\right)$ and the placenta $\left(5.0 \times 10^{2} \mathrm{copies} / \mathrm{mg}\right.$; dam all tissues negative at 11-months posthysterotomy). Fetus \#3 was only positive in the kidney $\left(2.6 \times 10^{1} \mathrm{copies} / \mathrm{mg}\right)$ and the placenta $\left(9.8 \times 10^{1}\right.$ copies/mg; dam all tissues negative at 9 -months posthysterotomy). Similarly, a small number of fetal tissues were Zika virus positive at $\sim 3$-months postinoculation with IP administration. Although two fetuses were negative for all tissues (dams also negative at 7- or 10-months posthysterotomy), one IP fetus was Zika virus positive in frontal and temporal lobes $\left(5.8 \times 10^{1}-1.8 \times 10^{2}\right.$ copies $/ \mathrm{mg}$; dam all tissues negative 
11-months posthysterotomy); one fetus was low positive in the kidneys $\left(8.8 \times 10^{1}\right.$ copies $/ \mathrm{mg}$; dam tissues collected same day and all negative); and one fetus was positive in frontal, parietal, and temporal lobes $\left(1.7 \times 10^{2}-1.1 \times 10^{3}\right.$ copies $\left./ \mathrm{mg}\right)$, cerebellum $\left(1.7 \times 10^{1}\right.$ copies $\left./ \mathrm{mg}\right)$, and optic nerve $\left(2.7 \times 10^{2}\right.$ $4.6 \times 10^{3}$ copies $/ \mathrm{mg}$ ) (dam negative for all tissues 10-months posthysterotomy). Amniotic fluid and fetal blood collected at hysterotomy were negative in all cases.

\section{Flow Cytometric Analysis}

We assessed maternal T-cell activation and maturation by following expression of CCR5, HLA-DR, and memory/effector subset markers. Maternal CCR5 expression by $\mathrm{CD} 4^{+} \mathrm{T}$-cells followed a pattern of early up regulation with a later decline similar to maternal viral loads (Fig. 2C,D). Indeed, maximum maternal viral loads and CCR5 expression appeared to be associated. The increased expression of CCR5 followed the early spike in maternal viral loads by 10-30 days. Interestingly, in two cases maternal CCR5 expression was maintained despite resolution of viremia (one red and one green line on right, Fig. 2C). One of these dams had tissues collected on the same day as fetal tissue collection (late third trimester, 145-days gestation) and another $\sim 1$ year later; Zika virus was not detected in the tissues of either dam.

\section{Immunohistochemical Analysis: Fetal Brain 3-Weeks Postinoculation}

The brain of a Zika virus-infected fetus was first assessed 3-weeks after fetal IP inoculation, and compared with cortical tissue from the right hemisphere of an age-matched control. Tissue blocks of fetal cerebrocortical tissue from the frontal, parietal/temporal, and occipital lobes were collected, fixed in $4 \%$ PFA, and $100 \mu \mathrm{m}$ thick sections were cut in the coronal plane on a vibratome. Sections were quadruple stained with combinations of markers labeling microglial cells (anti-Iba1), neural precursor cells (anti-Tbr2), radial glial cells (anti-GFAP), blood vessels (Isolectin B4), neurons, (anti-NeuN), and nuclei (DAPI).

In normally developing fetuses at 70-days gestation (second trimester), cerebral cortical microglia are often positioned as a single layer of cells close to the ventricle, at the boundary between the VZ and SVZ. Additional microglial cells are distributed sparsely across other laminar compartments in the fetal cortex (Cunningham et al. 2013b; Fig. 3A). This same distribution pattern was observed in the control fetus across cortical lobes (Fig. 3B,C). In contrast, the distribution of microglial cells was highly disorganized in the fetal brain $\sim 3$-weeks post-Zika virus inoculation. A large increase in the number and density of microglia were noted in the cortex. In addition, microglial cells were often concentrated in dense clusters throughout the cerebral proliferative zones in the frontal, parietal, temporal, and occipital lobes (Fig. 3D-F). The clusters of microglial cells ranged in size from 60 to $210 \mu \mathrm{m}$ in diameter, and were often associated with blood vessels (Fig. 4A,B). Microglial clusters were not observed in the control fetus (Fig. $3 A-F$ ), were associated with ectopic clusters of $\mathrm{Tbr} 2^{+}$precursor cells, and were noted in proliferative regions that were atypically devoid of $\mathrm{Tbr}^{+}$neural precursor cells and $\mathrm{GFAP}^{+}$cells (Fig. $3 \mathrm{~K}-\mathrm{O}$ ). Clusters located in regions devoid of typical cortical cell types may represent microglial cells that had displaced or phagocytosed the cortical cells that would normally be present (Cunningham et al. 2013b). Increased expression of the purinergic P2X7 receptor by microglial cells and endothelial cells within the clusters was also observed (Fig. 4F-M). Upregulated P2X7 expression in microglia has been correlated with an immune response during influenza infection (Leyva-Grado et al. 2017). The volume of the cortical proliferative zones occupied by microglial cells was quantified in optical stacks and compared across groups with Imaris image analysis software (Bitplane, Concord, MA). In the control fetus, microglia occupied $1.7 \pm 1.2 \%$ SD of the volume of cortical proliferative zones. In contrast, microglia occupied a 10 -fold greater volume in the proliferative zones after Zika virus inoculation $(11.7 \pm 3.9 \%$ SD $P<0.001$; Fig. $3 G)$.

We further examined the distribution of microglial cells in the proliferative zones by quantifying the volume microglia occupied in bins that spanned from the ventricular surface through the SVZ. Each bin was $640 \mu \mathrm{m}$ wide in the " $X$ " axis arranged parallel to the ventricular surface, $100 \mu \mathrm{m}$ in height in the " $Y$ " axis or radial dimension, and $15 \mu \mathrm{m}$ deep in the " $Z$ " axis. At 70-days gestation microglial cells were typically located near the ventricle, with a smaller volume of microglia in bins furthest from the lateral ventricle (Fig. $3 G$ ), whereas there was a 6- to 10 -fold increase of microglial volume in each bin in the fetus inoculated with Zika virus. Microglial distribution after Zika virus inoculation differed significantly when compared with the control $(P<0.0001)$.

Microglia in the normally developing second trimester fetal cortex typically exhibit a morphological phenotype traditionally identified as "activated". These cells extend a few thick processes, and some display large amoeboid somata with no processes or a few thin processes (Cunningham et al. 2013b; Barger et al. 2019). In general, microglial cells in the Zika virusinoculated fetus displayed morphological phenotypes similar to those present in normally developing fetuses. However, Zika virus was associated with a range of more complex morphological phenotypes. For example, we observed microglia with large membranous expansions that are typically associated with phagocytosis of neural precursor cells at later stages of development (Barger et al. 2019), and are uncommon in rhesus monkey cortical proliferative zones at 70-days gestation. Since microglia were clustered around blood vessels after Zika virus inoculation, blood vessels were labeled with Isolectin B4 (IB4), images were acquired with a confocal scanning microscope, and vessel structures quantified with Olympus Fluoview (Olympus) and Imaris Software (Bitplane, Concord, MA). Vessel diameter of the Zika virus inoculated fetus was greater when compared with the control (control: $7.67 \pm 0.2 \mu \mathrm{m}$; Zika virus: $12.03 \pm 0.6 \mu \mathrm{m}$; $P<0.0001$; Fig. 4E). We then quantified the total volume that blood vessels occupied in the cortical proliferative zones. IB4 ${ }^{+}$ blood vessels occupied $0.70 \pm 0.12 \%$ of the volume of cortical proliferative zones in the control fetus $(0.73 \pm 0.12 \%)$. However, blood vessel volume was increased 2-fold after Zika virus inoculation $(1.52 \pm 0.16 \% ; P<0.01)$ (Fig. $4 N$ ).

$\mathrm{Tbr}^{+}$neural precursor cells exhibit a bimodal distribution in the normally developing fetal cortex: $\mathrm{Tbr}^{+}$cells are concentrated in a dense inner band that is centered superficial to the VZ/SVZ boundary (Martínez-Cerdeño et al. 2012), and a diffuse outer band further from the lateral ventricle (Bulfone et al. 1999; Englund et al. 2005; Martínez-Cerdeño et al. 2012; Hevner 2019). In the typically developing fetal cortex microglia colonize proliferative zones (Cunningham et al. 2013b; Barger et al. 2019; Noctor et al. 2019) and regulate the size of the precursor cell pool through cellular phagocytosis of neural precursor cells (Cunningham et al. 2013b). Given the significant change in microglial cell distribution and density after Zika virus inoculation, we examined $\mathrm{Tbr} 2^{+}$cell distribution by quantifying 

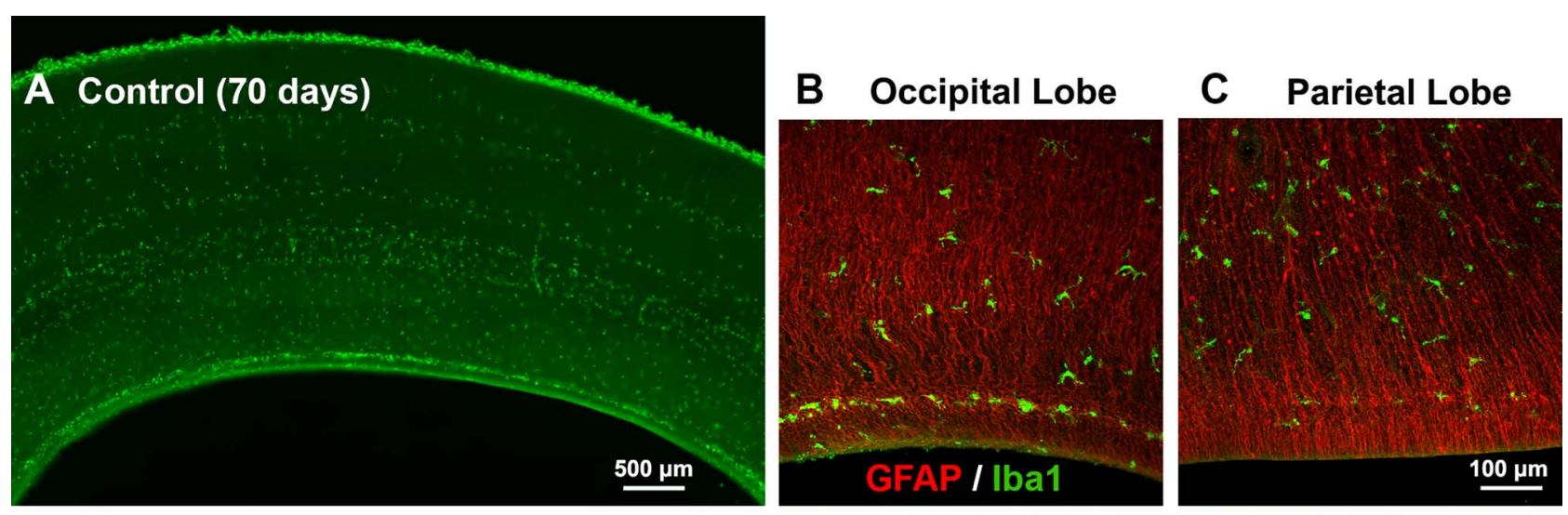

D Zika Virus (IP)
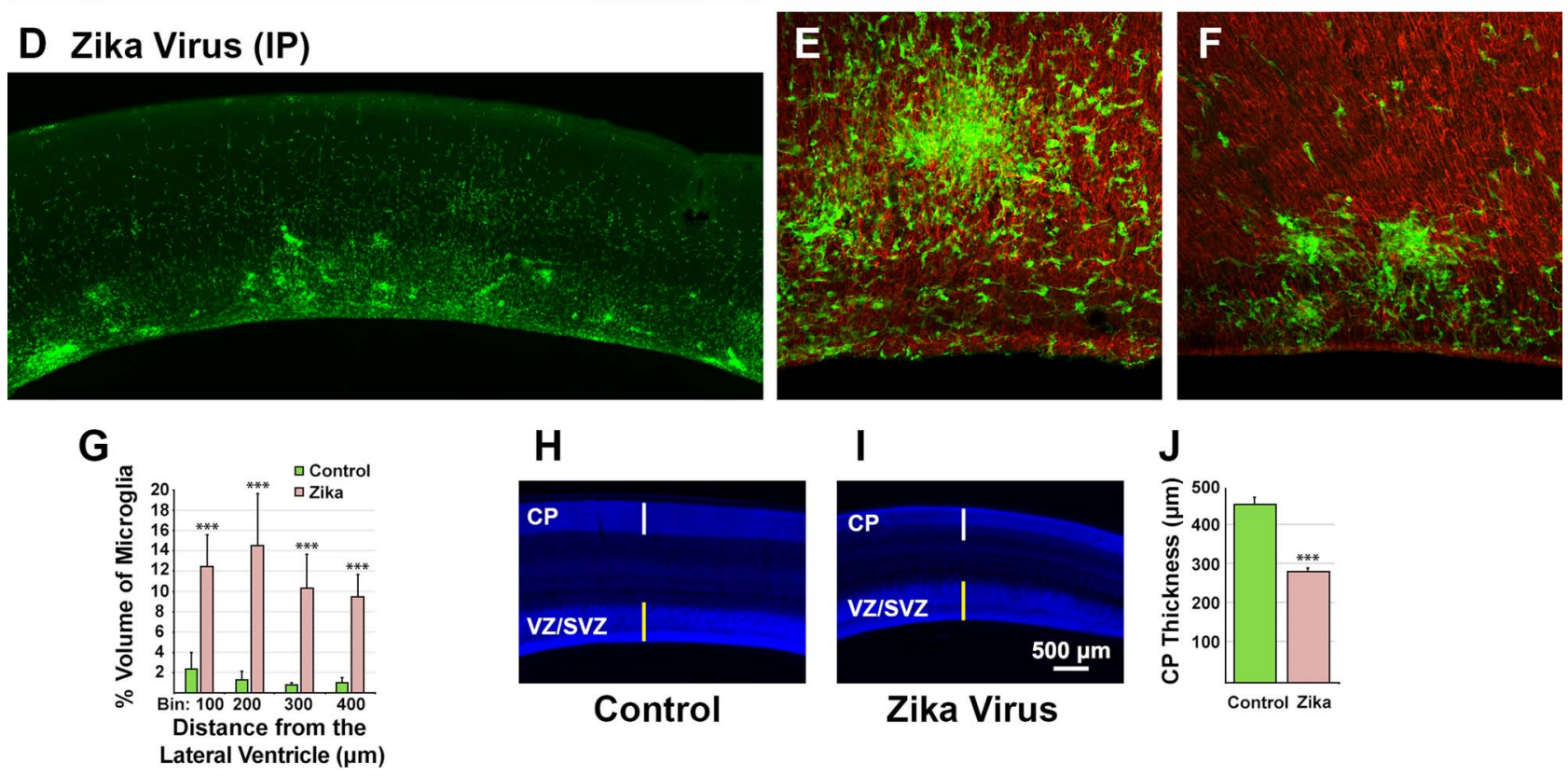

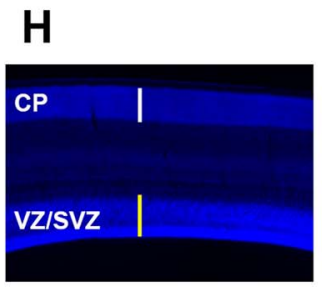

Control

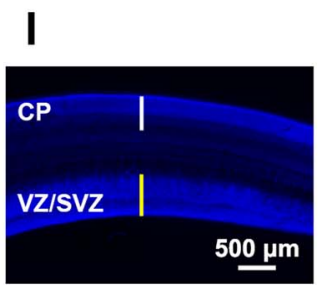

Zika Virus
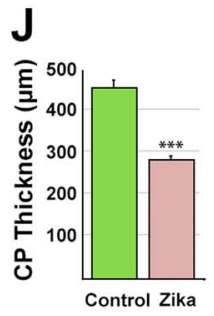
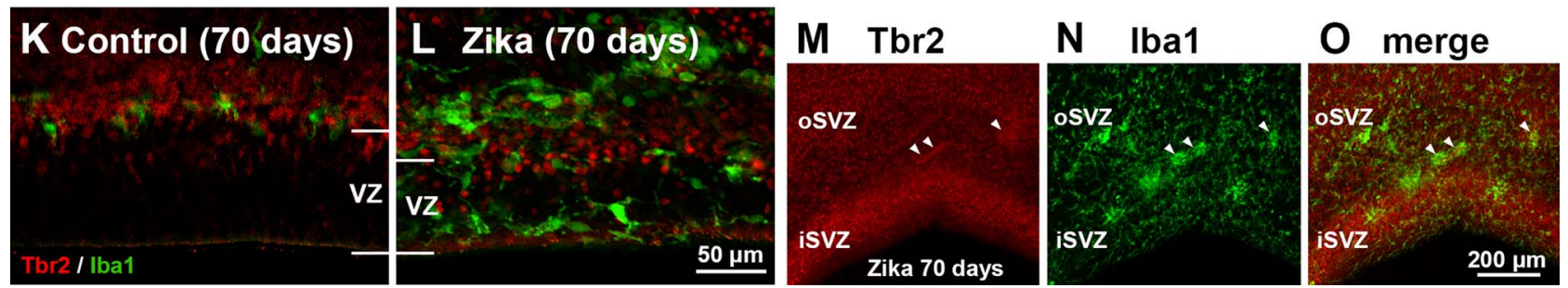

Figure 3. Fetal microglia distribution. (A) The distribution of Iba1 ${ }^{+}$microglial cells (green) in the occipital lobe of a normally developing fetus at 70-days gestation (second trimester). Microglia sparsely populate cortical proliferative zones at this stage of fetal development. Normal distribution of radial glial cells (GFAP, red) and microglia (green) in the control occipital lobe (B) and parietal lobe (C). (D) The number and density of Iba1 ${ }^{+}$microglial cells (green) was greatly increased in the 70 -day fetus, 3 weeks after inoculation with Zika virus. Microglia (Iba1, green) localized in abnormal clusters throughout cortical proliferative zones. (E, F) Abnormal microglial clusters (green) were present in proliferative zones of all cortical lobes. (G) Iba1 ${ }^{+}$microglial cells occupied a significantly larger volume of proliferative zones in the 70-day fetus, 3 weeks after Zika virus inoculation. Microglia occupied a 6- to 10-fold greater volume in the Zika virus inoculated (red bars) proliferative zone compared with the age-matched control (green bars). (H-J) The cortical wall was significantly thinner in the 70-day fetus 3 weeks after Zika virus inoculation compared with the control fetus. The cortical wall from the pial meninges to the ventricular surface, and the cortical plate (CP) were significantly thinner in the 70 -day fetus 3 weeks after Zika virus inoculation compared with the control. The vertical white line represents the thickness of the CP in control sections, and the vertical green line represents the thickness of the proliferative zones in control sections. (J) Histograms showing a significantly thinner cortical plate at 70 days, 3 weeks after Zika virus inoculation. $(\mathrm{K}, \mathrm{L}) \mathrm{Tbr}^{+}$precursor cells (red) were positioned closer to the ventricle, and distribution of Iba1 ${ }^{+}$microglia (green) was atypical in the 70 -day Zika virus inoculated fetus. (M-O) Ectopic clusters of Tbr2 ${ }^{+}$precursor cells (red) were present in the proliferative zones of the Zika virus inoculated fetus (white arrowheads) and colocalized with clusters of microglial cells (green). oSVZ = outer SVZ, iSVZ = inner SVZ.

the distance of $\mathrm{Tbr}^{+}$neural precursor cells from the lateral ventricle. We found that the dense inner band of $\mathrm{Tbr}^{+}$cells was significantly closer to the ventricle after Zika virus inoculation (control: $63.7 \pm 3.0 \mu \mathrm{m}$; Zika virus: $36.8 \pm 2.3 \mu \mathrm{m} ; P<0.001$ )
(Fig. 3K-L). These data are consistent with significant alterations in the cortical proliferative zones post-Zika virus inoculation.

Since $\mathrm{Tbr}^{+}$neural precursor cell position was altered in the 70-day fetus after Zika virus inoculation, and because Tbr2 ${ }^{+}$ 


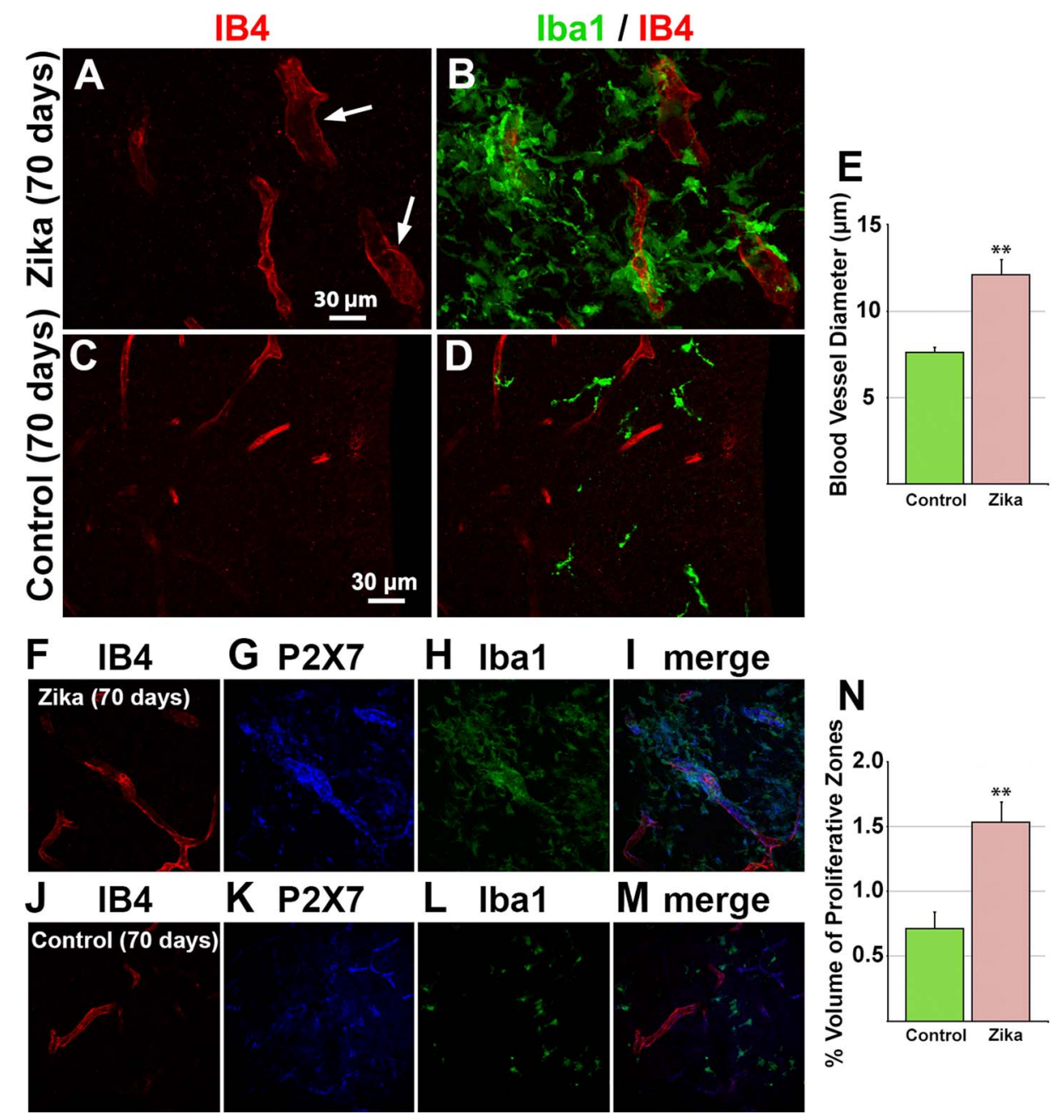

Figure 4. Blood vessel distribution. Blood vessels were larger in the 70-day brain 3 weeks after Zika virus inoculation compared with the control and were associated with increased P2X7 expression. (A) Large diameter Isolectin B4 (IB4)-positive vessels (red, white arrows) in the brain 3 weeks after Zika inoculation. (B) Microglia

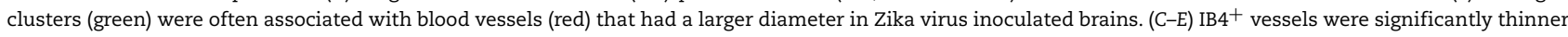
in control fetuses. (F-M) Expression of purinergic receptor P2X7 (blue) was increased in the cortex 3 weeks after Zika virus inoculation and was associated with both blood vessels (red) and microglia (green). (N) IB4 ${ }^{+}$blood vessels were larger and occupied twice the volume in cortical proliferative zones of the Zika virus inoculated brains (red bar) compared with control fetuses (green bar).

neural precursor cells produce cortical neurons (Englund et al. 2005), we quantified the thickness of the cortical gray matter and the cortical wall. The cortical plate was significantly thinner after Zika virus inoculation (control: $460 \pm 13.3 \mu \mathrm{m}$; Zika virus: $283 \pm 4.9 \mu \mathrm{m} ; \mathrm{P}<0.0001)$, and the thickness of the entire cortical wall from the lateral ventricle to pial meninges was thinner in the Zika virus inoculated fetus (control: $2307 \pm 86 \mu \mathrm{m}$; Zika virus: $1583 \pm 42 \mu \mathrm{m}: \mathrm{P}<0.0001$ ) (Fig. $3 \mathrm{H}-J$ ). Total brain weight was similar across the 70-day cohort ( $\sim 30 \mathrm{~g})$.

\section{Immunohistochemical Analysis: Fetal Brain 3-Months Postinoculation}

We next assessed cortical tissue from the right hemisphere of Zika virus-inoculated fetuses (IC and IP; $N=3$ per group) that were harvested in the late third trimester ( 145-days gestation; term $165 \pm 10$ days) and compared the tissues to those from fetal age-matched controls $(\mathrm{N}=3)$. Analysis of this cohort demonstrated that measurable developmental effects can occur as a result of Zika virus infection in the first trimester and can persist for at least 3-months postinoculation.

Cortical tissue from control and Zika-inoculated fetuses were immunostained with antibodies to label microglia (Iba1), astrocytes (GFAP), neurons (NeuN), mitotic cells (phosphohistone H3), blood vessels (IB4), and cells undergoing apoptosis (TUNEL). Qualitative assessment of microglia revealed that the overall range of morphological phenotypes in the occipital lobe of control and Zika virus inoculated fetuses appeared similar. However, in Zika virus inoculated fetuses we noted a small number of highly dysmorphic microglial cells that possessed very short, fragmented processes and resembled senescent microglia that are associated with neurodegenerative conditions (Lopes et al. 2008; Streit et al. 2009; Martínez-Cerdeño et al. 2018). Although the number of dysmorphic microglia was small in Zika virus inoculated fetuses, they were not observed in controls. There were also no qualitative differences in the morphology or distribution of GFAP ${ }^{+}$astrocytes. Quantitative evaluation of microglial cell morphology showed discrete, significant changes in cell 


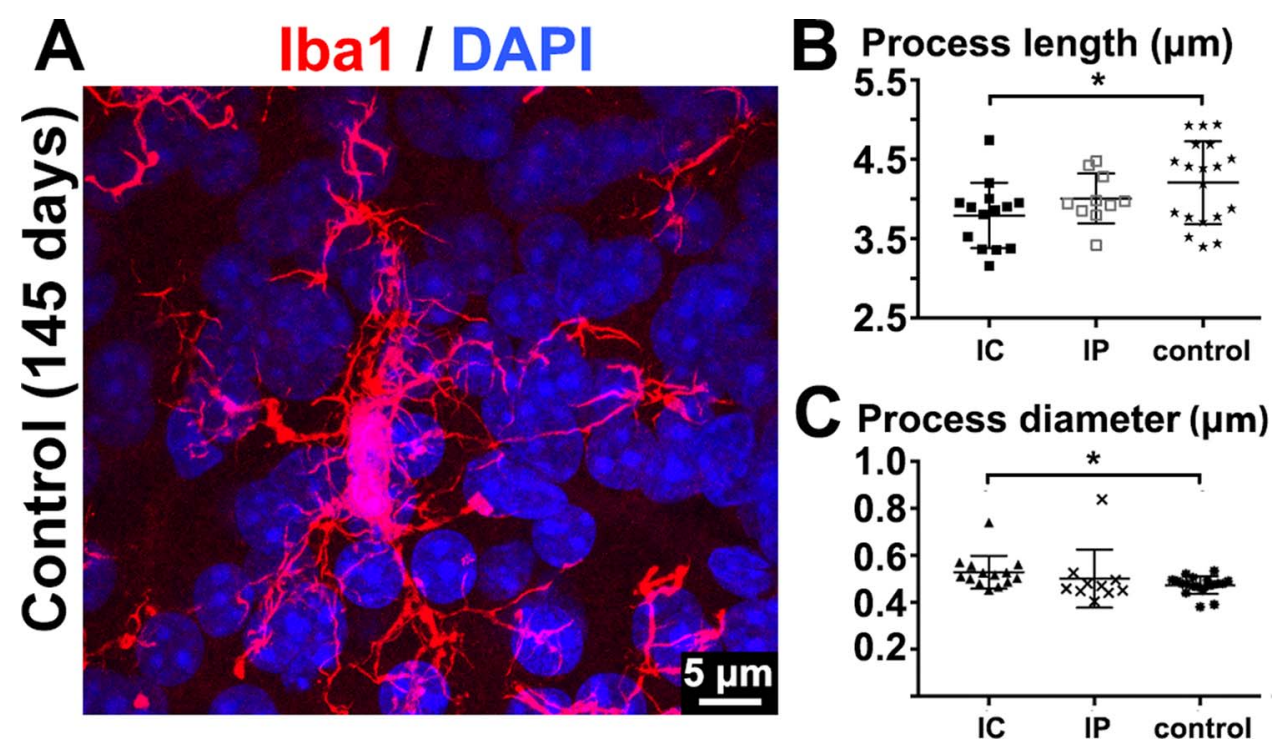

Figure 5. Cell morphology. (A) Control fetuses at 145-days gestation with 5 or 6 main processes radiated from microglial soma, and main processes that possessed numerous, finely branched processes. Cell morphological analysis indicated that microglial cell processes (B) were significantly shorter and (C) significantly thicker in the intracranial (IC) Zika virus inoculation group. IP = intraperitoneal.

shape. Double-blind analysis of $\mathrm{Iba1}^{+}$cell morphology using Imaris FilamentTracer (Bitplane) showed that microglial cell processes were shorter $(P<0.05)$; thicker $(P<0.02)$; and branched at sharper angles in Zika virus inoculated fetuses compared with age-matched controls $(P<0.0001)$, with posthoc tests indicating significance between the control and IC Zika virus inoculation group. Double-blind analyses also indicated that microglial processes were straighter in control fetuses when compared with fetal IP Zika virus inoculation $(P<0.0001)$. These data suggest that Zika virus exposure, through either route of infection, impacted fetal microglial cells and produced long-lasting changes in cellular morphology (Fig. 5A-C).

We next quantified the proportion of cortical tissue occupied by microglial cells in control and Zika virus groups. The volume of occipital lobe tissue occupied by Iba1 ${ }^{+}$cells as a proportion of total tissue volume was quantified and compared. In control fetuses, microglia occupied $6.3 \pm 0.92 \%$ SD of periventricular cortical volume. In fetuses that had been administered Zika virus by the IP route, microglia occupied more than double the volume of cortical tissue $\left(14.3 \pm 0.89 \%{ }^{\mathrm{SD}} ; \mathrm{P}<0.0001\right.$, ANOVA). Microglia occupied $9.1 \pm 1.81 \%$ SD of periventricular cortical tissue in fetuses that were inoculated by the IC route, but this was not found to be significantly different from controls (Fig. 6A-F). The increased proportion of tissue volume occupied by microglia in the control group during the second trimester (1.3\% at 70 days) compared with the third trimester ( $6.3 \%$ at 145 days) reflected the ongoing colonization of the cerebral cortex by microglia during gestation (Cunningham et al. 2013b). The increase in volume occupied by microglia in fetuses administered Zika virus from $11.7 \%$ at 70 days to $14.3 \%$ at 145 days may also partially reflect ongoing colonization. We also carried out qualitative and quantitative measures of other cortical cell types and did not detect a difference in the number of astrocytes, neurons, $\mathrm{PH}^{+}$ mitotic cells, or $\mathrm{TUNEL}^{+}$apoptotic cells when comparing groups in the periventricular region of the occipital lobe.

Vessels were stained with IB4, imaged, and volumetrically analyzed as above. IB4 ${ }^{+}$blood vessels occupied a similar volume of periventricular cortical tissue in the control and IC-inoculated fetuses in the third trimester $(1.36 \pm 0.7 \%$ vs. $1.44 \pm 1.39 \%)$, whereas the volume occupied was modestly elevated after IP inoculation $(2.4 \pm 1.9 \% ; P<0.001)$ (Fig. $6 \mathrm{~A}-\mathrm{C}, \mathrm{G}$ ).

Sections of the occipital lobe were labeled with DAPI and imaged. Cortical gray matter was identified, and 9 measurements were made at the same points for each fetus in all groups using Zeiss Fluoview software. The thickness of the cortical plate in control fetuses measured $845.20 \pm 62.53 \mu \mathrm{m}^{\mathrm{SD}}$; fetal IP Zika virus measured $820.70 \pm 61.14 \mu \mathrm{m}^{\mathrm{SD}}$, and fetal IC inoculation was $770.40 \pm 31.92 \mu \mathrm{m}^{\mathrm{SD}}$; ANOVA and Tukey posthoc analysis showed that the cortical plate was significantly thinner in both the Zika virus IC $(P<0.0001)$ and IP $(P<0.01)$ groups.

Finally, we considered if fetal cortical and maternal effects of Zika virus were correlated. We used orthogonal partial least squares (OPLS) to derive a quantitative score reflecting the total impact of Zika virus infection on cortical measures. The scores derived by OPLS identify a combination of predictive variables that best discriminate animals in the control versus Zika virus-infected groups (Trygg and Wold 2002) (Fig. 6H). The algorithm identified the percent microglial volume at 100-200 microns from the lateral ventricle as most different and also provided a summary score (Axis 1) that could be correlated with viral loads and immune activation. Interestingly, the summary score was not obviously associated with detection of Zika virus nucleic acid in the fetal brain (Fig. 2B). Although associations with maternal viremia or immune activation did not reach statistical significance, we found that the fetus with the highest OPLS score manifested the highest maternal viral load and nearhighest maternal CCR5 expression. Data points for this fetus are emphasized in Figure 2 with a "plus" marker in the graphs and a dotted line overlaid on traces.

\section{DISCUSSION}

Microglial cells are the innate immune cells of the cerebral cortex. The physiological roles of microglia in the mature brain have been extensively studied (Wolf et al. 2017), but the functional role(s) of microglia in the prenatal brain are not yet 

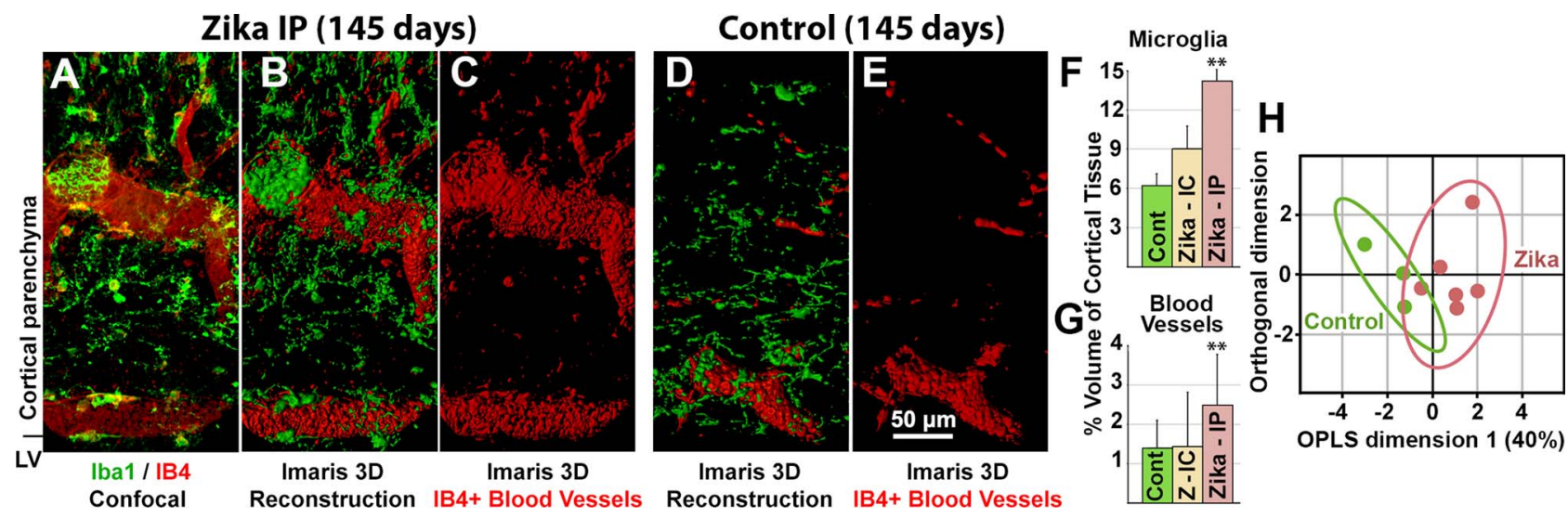

Figure 6. Blood vessels were larger and associated with increased P2X7 expression with Zika virus exposure. (A) Confocal image of immunostained brain section that indicates microglia clusters (green) were often associated with large diameter blood vessels (red). (B, C) 3D Imaris reconstruction of the same image for quantification of blood vessel (red) and microglial cell (green) volume in the cerebral cortex. Large diameter IB4-positive vessels (red and white arrows) 3 months after Zika virus inoculation ( 145-days gestation). (D, E) 3D Imaris reconstruction from a control fetus at a comparable gestational age showing blood vessels (red) and microglial cells (green) in the cerebral cortex. (F, G) Histograms indicate that microglial cell volume and blood vessel volume was significantly increased 2-fold in the fetal brain 3 months after Zika virus inoculation IP (red bars), although significance was not detected with IC inoculation (yellow bars) and when compared with age-matched controls (green bars). (H) The score derived by orthogonal partial least squares (OPLS; dimension 1) is a summary measure of cortical abnormality that discriminates control from Zika-infected animals. The percent microglial volume at 100-200 microns from the lateral ventricle was the greatest contributor to this score. The animal with the highest OPLS score is rightmost on the abscissa and tracked in Figure 2.

fully understood. Microglia begin to colonize the rhesus monkey cerebral cortex during the first trimester (prior to 50-days gestation) (Cunningham et al. 2013a,b), and the human cerebrum by 6-weeks gestation (Andjelkovic et al. 1998; Verney et al. 2010). Microglia initially colonize specific regions and laminae of the prenatal telencephalon that include cortical proliferative zones surrounding the lateral ventricles (Rezaie and Male 1999; Cunningham et al. 2013a,b; Swinnen et al. 2013; Arnò et al. 2014). Microglia participate in key developmental programs in the early postnatal period that include the establishment of axonal pathways (Squarzoni et al. 2014), synapse development and maintenance (Paolicelli et al. 2011; Schafer et al. 2012; Salter and Stevens 2017), and cortical layer formation (Ueno et al. 2013; Squarzoni et al. 2014). We previously demonstrated that during prenatal development microglia are an intrinsic component of the cortical proliferative zones (Barger et al. 2019), make extensive contact with mitotic neural precursor cells (Noctor et al. 2019), and regulate cell production in the prenatal cortex by phagocytosing neural precursor cells in the VZ and SVZ, particularly in rhesus monkeys (Cunningham et al. 2013b).

In these studies, we found that fetal Zika virus inoculation during the late first trimester was associated with significant changes in the fetal cerebral cortex at 3 weeks (70-days gestation) and 3 months (145-days gestation) postinoculation. The changes observed include massive alterations in the distribution, morphology, and volume of microglial cells in proliferative and periventricular regions of the fetal cerebral cortex; an altered distribution of cortical neural precursor cells; increased diameter and volume of blood vessels in the cortical proliferative and periventricular zones; and a thinner cortical plate. Disturbances in microglial cell distribution occurred rapidly after fetal infection. We have previously reported that microglial cells phagocytose Tbr2-expressing neural precursor cells in the fetal rhesus monkey during normal cortical development (Cunningham et al. 2013b). Tbr2-expressing neural precursor cells are produced through the mitotic divisions of Pax6-expressing radial glial cells (Noctor et al. 2001, 2002, 2004, 2008; Englund et al. 2005), and evidence suggests that radial glia express the AXL viral entry receptor (Nowakowski et al. 2016). If radial glial cells are indeed among the initial targets of fetal Zika virus infection, the virus could potentially be passed down to Tbr2-expressing daughter cells. Zika virus infected Tbr2 ${ }^{+}$cells could therefore become targets of microglial cells, potentially explaining the clustered microglial cells in the cortical proliferative zones (see Fig. 3D-F). Alternatively, Tbr2-expressing neural precursor cells may also be included among primary targets of Zika virus infection. Indeed, it has been reported that Zika virus infection is associated with mitotic abnormalities and apoptosis of primary neural precursor cells (Souza et al. 2016), questioning the capacity for Zika virusinfected radial glia to effectively divide and produce neuronal progeny such as $\mathrm{Tbr}^{+}$daughter cells. The presence of $\mathrm{Tbr}^{+}$ neural precursor cells in the SVZ (see Fig. $3 \mathrm{M}-\mathrm{P}$ ) indicates that radial glia produced $\mathrm{Tbr} 2^{+}$daughter cells after Zika virus inoculation. However, it is possible that the ectopic clusters of Tbr2 ${ }^{+}$ neural precursor cells represented the progeny of infected radial glia and these $\mathrm{Tbr}^{+}$cells were targeted by microglia, whereas the population of $\mathrm{Tbr}^{+}$cells that attained a normal laminar distribution represent the progeny of radial glia that escaped infection after inoculation. This model of infection would be expected to produce a mosaic of normal and infected cells throughout the cortical lobes, each exhibiting distinct behaviors, fates, and influence on formation of the cerebral cortex.

We also noted an association of microglial clusters with blood vessels in the Zika virus inoculated fetuses. Blood vessel diameter was significantly larger, and the volume of the cortical proliferative and periventricular zones occupied by blood vessels was increased 2-fold at both 3-weeks and 3months postinoculation (Figs $4 E$ and $6 G$ ). These findings are in line with reports showing that endothelial cells-a key component of developing vasculature in the fetal brain-also express the AXL receptor and are prime targets of infection (Richard et al. 2017). Zika administration in gravid ferrets produced a similar increase in cortical vessel size in the embryonic ferret cortex (Hutchinson et al. 2019), whereas studies 
in the mouse have reported a decrease in vascular density and vessel branching (Garcez et al. 2018). These contrasting findings, particularly between embryonic mouse and fetal rhesus monkey, may represent species differences, contrasting patterns of vascular development between lissencephalic versus gyrencephalic cortices, and/or differences in methodology. For example, we quantified vessels in periventricular regions adjacent to the lateral ventricle in fetal rhesus monkey cortex, whereas Garcez and colleagues analyzed vasculature across the width of the lissencephalic mouse cortex (Garcez et al. 2018). Future analysis of cortical vasculature throughout the rhesus monkey telencephalon may shed further light on the impact of Zika virus on vessel development in this species. The volume of cortical tissue occupied by $\mathrm{Iba}^{+}$microglial cells was increased 6-fold at 3-weeks postinoculation and remained significantly elevated 2 -fold at 3 -months postinoculation. The proliferative zones in the fetal brain are highly enriched with neural precursor cells and blood vessels. Our finding that microglial cell clusters formed around blood vessels and ectopic clusters of neural precursor cells is consistent with the concept that Zika virus infection across fetal neural precursor and endothelial cells were targeted by attendant microglial cells that normally inhabit the fetal proliferative zones.

In addition to an altered distribution of microglial cells and blood vessel structure we found that fetal Zika virus was associated with thinning of the cortical gray matter. The cortical gray matter was notably thinner at 3-weeks postinoculation $(283 \mu \mathrm{m}$ vs. $460 \mu \mathrm{m})$ and remained significantly thinner at 3-months postinoculation $(770 \mu \mathrm{m}$ vs. $845 \mu \mathrm{m})$. Taken together, our results demonstrate a strong and persistent effect of Zika virus inoculation on central features of fetal cortical development. These data further support that rhesus monkeys are an important nonhuman primate model for revealing mechanisms that can result in deficits in human brain structural development, particularly those associated with Zika virus and other neuroteratogens.

\section{Notes}

Conflict of Interest: The authors have no financial interests that would represent a conflict of interest.

\section{Funding}

These studies were supported by National Institutes of Health (NIH) grants (nos. OD023716, NS103658, NS109379), and the NIH Primate Center base operating grant (no. OD011107). In vivo imaging was performed with instrumentation funded by the NIH (S10 grants nos. OD016261 and RR025063).

\section{References}

Aliota MT, Bassit L, Bradrick SS, Cox B, Garcia-Blanco MA, Gavegnano C, Friedrich TC, Golos TG, Griffin DE, Haddow AD et al. 2017. Zika in the Americas in year 2: what have we learned? What gaps remain? A report from the global virus network. Antiviral Res. 144:223-246.

Andjelkovic AV, Nikolic B, Pachter JS, Zecevic N. 1998. Macrophages/microglial cells in human central nervous system during development: an immunohistochemical study. Brain Res. 814:13-25.

Arnò B, Galli F, Roostalu U, Aldeiri BM, Miyake T, Albertini A, Bragg L, Prehar S, McDermott JC, Cartwright EJ et al. 2014.
Neural progenitor cells orchestrate microglia migration and positioning into the developing cortex. Nat Commun. 5:5611.

Arora HS. 2020. A to Z of Zika virus: a comprehensive review for clinicians. Glob Pediatr Health. 7: 2333794X20919595.

Bachiller S. 2018. Microglia in neurological diseases: a road map to brain-disease dependent-inflammatory response. Front Cell Neurosci. 12:1-17.

Barger N, Keiter J, Kreutz A, Krishnamurthy A, Weidenthaler C, Martínez-Cerdeño V, Tarantal AF, Noctor SC. 2019. Microglia: an intrinsic component of the proliferative zones in the fetal rhesus monkey (Macaca mulatta) cerebral cortex. Cereb Cortex. 29:2782-2796.

Barry PA, Lockridge KM, Salamat S, Tinling SP, Yue Y, Zhou SS, Gospe SM Jr, Britt WJ, Tarantal AF. 2006. Nonhuman primate models of intrauterine cytomegalovirus infection. ILAR J. 47:49-64.

Batchelder CA, Lee CC, Martinez ML, Tarantal AF. 2010. Ontogeny of the kidney and renal developmental markers in the rhesus monkey (Macaca mulatta). Anat Rec (Hoboken). 293: 1971-1983.

Bulfone A, Martinez S, Marigo V, Campanella M, Basile A, Quaderi N, Gattuso C, Rubenstein JL, Ballabio A. 1999. Expression pattern of the Tbr2 (Eomesodermin) gene during mouse and chick brain development. Mech Dev. 84:133-138.

Caine EA, Jagger BW, Diamond MS. 2018. Animal models of Zika virus infection during pregnancy. Viruses. 10:1-21.

Centers for Disease Control (CDC) website: https://www.cdc.go v/pregnancy/zika/testing-follow-up/zika-syndrome-birthdefects.html (accessed October 18, 2020).

Chang WLW, Tarantal AF, Zhou SS, Borosky AD, Barry PA. 2002. A recombinant rhesus cytomegalovirus expressing enhanced green fluorescent protein retains wild-type replication and pathogenic potential in fetal macaques. J Virol. 76:9493-9504.

Counotte MJ, Kim CR, Wang J, Bernstein K, Deal CD, Broutet NJN, Low N. 2018. Sexual transmission of Zika virus and other flaviviruses: a living systematic review. PLoS Med. 15:e1002611.

Coyne CB, Lazear HM. 2016. Zika virus - reigniting the TORCH. Nat Reu Microbiol. 14:707-715.

Cunningham CL, Martínez-Cerdeño V, Noctor SC. 2013a. Diversity of neural precursor cell types in the prenatal macaque cerebral cortex exists largely within the astroglial cell lineage. PLoS One. 8:e63848.

Cunningham CL, Martínez-Cerdeño V, Noctor SC. $2013 \mathrm{~b}$. Microglia regulate the number of neural precursor cells in the developing cerebral cortex. J Neurosci. 33:4216-4233.

Dudley DM, Aliota MT, Mohr EL, Newman CM, Golos TG, Friedrich TC, O'Connor DH. 2019. Using macaques to address critical questions in Zika virus research. Annu Rev Virol. 6:481-500.

Eick SM, Dale AP, McKay B, Lawrence C, Ebell MH, Cordero JF, Welton M. 2019. Seroprevalence of dengue and Zika virus in blood donations: a systematic review. Transfus Med Rev. 33:35-42.

Englund C, Fink A, Lau C, Pham D, Daza RA, Bulfone A, Kowalczyk T, Hevner RF. 2005. Pax6, Tbr2, and Tbr1 are expressed sequentially by radial glia, intermediate progenitor cells, and postmitotic neurons in developing neocortex. J Neurosci. 25:247-251.

Ferraris P, Cochet M, Hamel R, Gladwyn-Ng I, Alfano C, Diop F, Garcia D, Talignani L, Montero-Menei CN, Nougairède A et al. 2019. Zika virus differentially infects human neural progenitor cells according to their state of differentiation and dysregulates neurogenesis through the Notch pathway. Emerg Microbes Infect. 8:1003-1016. 
Garcez PP. 2016. Zika virus impairs growth in human neurospheres and brain organoids. Science. 352:816-818.

Garcez PP, Stolp HB, Sravanam S, Christo RR, Ferreira JCCG, Dias AA, Pezzuto P, Higa LM, Barbeito-Andrés J, Ferreira RO et al. 2018. Zika virus impairs development of blood vessels in a mouse model of congenital infection. Sci Rep. 8:12774.

Ginhoux F, Greter M, Leboeuf M, Nandi S, See P, Gokhan S, Mehler MF, Conway SJ, Ng LG, Stanley ER, Samokhvalov IM, Merad M. 2010. Fate mapping analysis reveals that adult microglia derive from primitive macrophages. Science. 330:841-845.

Gratton R, Tricarico PM, Agrelli A, Colaço da Silva HV, Coêlho Bernardo L, Crovella S, Campos Coelho AV, Rodrigues de Moura R, Cavalcanti Brandão LA. 2020. In vitro Zika virus infection of human neural progenitor cells: meta-analysis of RNA-Seq assays. Microorganisms. 8:1-13.

Hanners NW, Eitson JL, Usui N, Richardson RB, Wexler EM, Konopka G, Schoggins JW. 2016. Western Zika virus in human fetal neural progenitors persists long term with partial cytopathic and limited immunogenic effects. Cell Rep. 15:2315-2322.

Hastings AK, Fikrig E. 2017. Zika virus and sexual transmission: a new route of transmission for mosquito-borne flaviviruses. Yale J Biol Med. 90:325-330.

Hevner RF. 2019. Intermediate progenitors and Tbr2 in cortical development. J Anat. 235:616-625.

Hutchinson EB, Chatterjee M, Reyes L, Djankpa FT, Valiant WG, Dardzinski B, Mattapallil JJ, Pierpaoli C, Juliano SL. 2019. The effect of Zika virus infection in the ferret. J Comp Neurol. 527:1706-1719.

Jimenez A, Shaz BH, Bloch EM. 2017. Zika virus and the blood supply: what do we know? Transfus Med Rev. 31:1-10.

Jimenez DF, Lee CI, O'Shea CE, Kohn DB, Tarantal AF. 2005. HIV-1derived lentiviral vectors and fetal route of administration on transgene biodistribution and expression in rhesus monkeys. Gene Ther. 12:821-830.

Kettenmann H, Hanisch U-K, Noda M, Verkhratsky A. 2011. Physiology of microglia. Physiol Rev. 91:461-553.

Lee CC, Fletcher MD, Tarantal AF. 2005. Effect of age on the frequency, cell cycle, and lineage maturation of rhesus monkey (Macaca mulatta) $\mathrm{CD} 34^{+}$and hematopoietic progenitor cells. Pediatr Res. 58:315-322.

Leyva-Grado VH, Ermler ME, Schotsaert M, Gonzalez MG, Gillespie V, Lim JK, García-Sastre A. 2017. Contribution of the purinergic receptor P2X7 to development of lung immunopathology during influenza virus infection. MBio. 8:e00229-e00217.

Lopes KO, Sparks DL, Streit WJ. 2008. Microglial dystrophy in the aged and Alzheimer's disease brain is associated with ferritin immunoreactivity. Glia. 56:1048-1060.

Lum FM, Low DK, Fan Y, Tan JJ, Lee B, Chan JK, Rénia L, Ginhoux F, Ng LF. 2017. Zika virus infects human fetal brain microglia and induces inflammation. Clin Infect Dis. 64:914-920.

Martínez-Cerdeño V, Cunningham CL, Camacho J, Antczak JL, Prakash AN, Cziep ME, Walker AI, Noctor SC. 2012. Comparative analysis of the subventricular zone in rat, ferret, and macaque: evidence for an outer subventricular zone in rodents. PLoS One. 7:e30178.

Martínez-Cerdeño V, Hong T, Amina S, Lechpammer M, Ariza J, Tassone F, Noctor SC, Hagerman P, Hagerman R. 2018. Microglial cell activation and senescence are characteristic of the pathology of FXTAS. Mov Disord. 33:1887-1894.

Mulkey SB, Arroyave-Wessel M, Peyton C, Bulas DI, Fourzali Y, Jiang J, Russo S, McCarter R, Msall ME, du Plessis AJ et al. 2020.
Neurodevelopmental abnormalities in children with in utero Zika virus exposure without congenital Zika syndrome.JAMA Pediatr. 174:269-276.

Neu N, Duchon J, Zachariah P. 2015. TORCH infections. Clin Perinatol. 42:77-103.

Newman C, Friedrich TC, O'Connor DH. 2017. Macaque monkeys in Zika virus research: 1947-present. Curr Opin Virol. 25: 34-40.

Noctor SC, Flint AC, Weissman TA, Dammerman RS, Kriegstein AR. 2001. Neurons derived from radial glial cells establish radial units in neocortex. Nature. 409:714-720.

Noctor SC, Flint AC, Weissman TA, Wong WS, Clinton BK, Kriegstein AR. 2002. Dividing precursor cells of the embryonic cortical ventricular zone have morphological and molecular characteristics of radial glia. J Neurosci. 22:3161-3173.

Noctor SC, Martínez-Cerdeño V, Ivic L, Kriegstein AR. 2004. Cortical neurons arise in symmetric and asymmetric division zones and migrate through specific phases. Nat Neurosci. 7:136-144.

Noctor SC, Martínez-Cerdeño V, Kriegstein AR. 2008. Distinct behaviors of neural stem and progenitor cells underlie cortical neurogenesis. J Comp Neurol. 508:28-44.

Noctor SC, Penna E, Shepherd H, Chelson C, Barger N, MartínezCerdeño V, Tarantal AF. 2019. Periventricular microglial cells interact with dividing precursor cells in the nonhuman primate and rodent prenatal cerebral cortex. J Comp Neurol. 527:1598-1609.

Nowakowski TJ, Pollen AA, Di Lullo E, Sandoval-Espinosa C, Bershteyn M, Kriegstein AR. 2016. Expression analysis highlights AXL as a candidate Zika virus entry receptor in neural stem cells. Cell Stem Cell. 18:591-596.

Paolicelli RC, Bolasco G, Pagani F, Maggi L, Scianni M, Panzanelli P, Giustetto M, Ferreira TA, Guiducci E, Dumas L et al. 2011. Synaptic pruning by microglia is necessary for normal brain development. Science. 333:1456-1458.

Pierson TC, Diamond MS. 2020. The continued threat of emerging flaviviruses. Nat Microbiol. 5:796-812.

Rakic P. 1974. Neurons in rhesus monkey visual cortex: systematic relation between time of origin and eventual disposition. Science. 183:425-427.

Ramsey EM, Houston ML, Harris JW. 1976. Interactions of the trophoblast and maternal tissues in three closely related primate species. Obstet Gynecol. 124:647-652.

Rasmussen SA, Jamieson DJ, Honein MA, Peterson LR. 2016. Zika virus and birth defects-reviewing the evidence for causality. N Engl J Med. 374:1981-1987.

Rezaie P, Male D. 1999. Colonisation of the developing human brain and spinal cord by microglia: a review. Microsc Res Tech. 45:359-382.

Richard AS, Shim BS, Kwon YC, Zhang R, Otsuka Y, Schmitt K, Berri F, Diamond MS, Choe H. 2017. AXL-dependent infection of human fetal endothelial cells distinguishes Zika virus from other pathogenic flaviviruses. Proc Natl Acad Sci U S A. 114:2024-2029.

Salter MW, Stevens B. 2017. Microglia emerge as central players in brain disease. Nat Med. 23:1018-1027.

Schafer DP, Lehrman EK, Kautzman AG, Koyama R, Mardinly AR, Yamasaki R, Ransohoff RM, Greenberg ME, Barres BA, Stevens B. 2012. Microglia sculpt postnatal neural circuits in an activity and complement-dependent manner. Neuron. 74:691-705.

Sekar A, Bialas AR, de Rivera H, Davis A, Hammond TR, Kamitaki N, Tooley K, Presumey J, Baum M, Van Doren V et al. 2016. 
Schizophrenia risk from complex variation of complement component 4. Nature. 530:177-183.

Sharma V, Sharma M, Dhull D, Sharma Y, Kaushik S, Kaushik S. 2020. Zika virus: an emerging challenge to public health. Can J Microbiol. 66:87-98.

Smart IHM, Dehay C, Giroud P, Berland M, Kennedy H. 2002. Unique morphological features of the proliferative zones and postmitotic compartments of the neural epithelium giving rise to striate and extrastriate cortex in the monkey. Cereb Cortex. 12:37-53.

Souza BS, Sampaio GL, Pereira CS, Campos GS, Sardi SI, Freitas LA, Figueira CP, Paredes BD, Nonaka CK, Azevedo CM et al. 2016. Zika virus infection induces mitosis abnormalities and apoptotic cell death of human neural progenitor cells. Sci Rep. 6:39775.

Squarzoni P, Oller G, Hoeffel G, Pont-Lezica L, Rostaing P, Low D, Bessis A, Ginhoux F, Garel S. 2014. Microglia modulate wiring of the embryonic forebrain. Cell Rep. 8:1271-1279.

Streit WJ, Braak H, Xue Q-S, Bechmann I. 2009. Dystrophic (senescent) rather than activated microglial cells are associated with tau pathology and likely precede neurodegeneration in Alzheimer's disease. Acta Neuropathol. 118:475-485.

Sutarjono B. 2019. Can we better understand how Zika leads to microcephaly? A systematic review of the effects of the Zika virus on human brain organoids. J Infect Dis. 219:734-745.

Swinnen N, Smolders S, Avila A, Notelaers K, Paesen R, Ameloot M, Brône B, Legendre P, Rigo JM. 2013. Complex invasion pattern of the cerebral cortex by microglial cells during development of the mouse embryo. Glia. 61:150-163.
Tang H, Hammack C, Ogden SC, Wen Z, Qian X, Li Y, Yao B, Shin J, Zhang F, Lee EM et al. 2016. Zika virus infects human cortical neural progenitors and attenuates their growth. Cell Stem Cell. 18:587-590.

Tarantal AF. 2005. Ultrasound imaging in rhesus (Macaca mulatta) and long-tailed (Macaca fascicularis) macaques. Reproductive and research applications. In: The Laboratory Primate Ch. 20. Cambridge: Elsevier Academic Press, pp. 315-317.

Tarantal AF, McDonald RJ, Jimenez DF, Lee CCI, O'Shea CE, Leapley AC, Won RH, Plopper CG, Lutzko C, Kohn DB. 2005. Intrapulmonary and intramyocardial gene transfer in rhesus monkeys (Macaca mulatta): safety and efficiency of HIV-1derived lentiviral vectors for fetal gene delivery. Mol Ther. 12:87-98.

Trygg J, Wold S. 2002. Orthogonal projections to latent structures (O-PLS). J Chemometr. 16:119-128.

Ueno M, Fujita Y, Tanaka T, Nakamura Y, Kikuta J, Ishii M, Yamashita T. 2013. Layer V cortical neurons require microglial support for survival during postnatal development. Nat Neurosci. 16:543-551.

Verney C, Monier A, Fallet-Bianco C, Gressens P. 2010. Early microglial colonization of the human forebrain and possible involvement in periventricular white-matter injury of preterm infants. J Anat. 217:436-448.

Wolf SA, Boddeke HWGM, Kettenmann H. 2017. Microglia in physiology and disease. Annu Rev Physiol. 79:619-643.

Xu D, Li C, Qin CF, Xu Z. 2019. Update on the animal models and underlying mechanisms for ZIKV-induced microcephaly. Annu Rev Virol. 6:459-479. 